\title{
Carbohydrate metabolism in floral structures of Lilium pumilum in different development stages
}

\author{
Alterações no teor de carboidratos em estruturas florais de \\ Lilium pumilum em diferentes estádios de desenvolvimento
}

\author{
Mirelle Nayana de Sousa Santos ${ }^{\mathrm{I}}$ Ana Maria Mapeli ${ }^{\mathrm{II}}$ Márcia Martins Tolentino ${ }^{\mathrm{II}}$
}

\section{- NOTE -}

\section{ABSTRACT}

Lilium pumilum is a species that stands out in floriculture for presenting orange inflorescences that attract the consumer. This study thus aimed at characterizing the carbohydrate metabolism of floral structures of $\boldsymbol{L}$. pumilum in different development stages. For this purpose, carbohydrate levels (total soluble sugars, reducing sugars, non-reducing sugars, and starch), at different floral stages (EO - bud with no color; E1 - bud at early coloring; E2 - orange bud; E3 - open flower; E4 - senescent flower) were quantified after extraction with ethanol. Lilium pumilum flowers showed high energy potential during floral opening and senescence; total soluble sugars were the main carbohydrates present in the species, reducing with the floral development, and the same occurred with the non-reducing sugar and starch contents. The reducing-sugar content increased with the floral stages. Therefore, this species presents great mobilization of compounds, which are utilized in the production of energy that is employed in floral opening.

Key words: total soluble sugars, starch, lily.

\section{RESUMO}

Lilium pumilum é uma espécie que se destaca na floricultura, por apresentar inflorescências alaranjadas que atraem o consumidor. Assim, este trabalho teve como objetivo caracterizar o metabolismo de carboidrato de estruturas florais de L. pumilum em diferentes estádios de desenvolvimento. Para isso, os niveis de carboidratos (açúcares solúveis totais, açúcares redutores, açúcares não redutores e amido), em diferentes estádios florais (E0 - botão sem coloração; E1 - botão em início de coloração; E2 - botão alaranjado; E3 - flor aberta; E4 - flor senescente), foram quantificados a partir da extração com etanol. As flores de L. pumilum apresentaram um alto potencial energético durante a abertura floral e senescência, sendo os açúcares solúveis totais os principais carboidratos presentes na espécie, mas com redução de acordo com o desenvolvimento floral, o mesmo ocorrendo com os teores de açúcar não redutor e amido. $O$ conteúdo de açúcar redutor foi crescente entre os estádios florais. Portanto, a espécie apresenta grande mobilização de compostos, os quais são utilizados na produção de energia, que é empregada na abertura floral.

Palavras-chave: açúcares solúveis totais, amido, lírio.

One of the decisive aspects in the advance of the Brazilian flower industry is the cultivation of native and/or introduced species with decorative potential that feature good adaptability to environmental conditions of diverse regions (SANTOS et al., 2008). Cultivation of lily (Lilium spp.), for example, for the production of cut flowers, has substantially increased in the last decades (BARBOSA et al., 2005). According to the Brazilian Institute of Floriculture, there was an increase in lily sales between 2013 and 2014, with $10.6 \%$ as cut flowers (IBRAFLOR, 2014).

Despite this advance, the flower industry faces the problem of product losses even before it reaches the consumer, mainly due to post-harvest losses. Most losses are caused by the increased plant metabolism, including the increased respiratory rate, responsible for the intake of organic compounds. Of these compounds, the carbohydrates stand out for being the main sources of carbon and energy for the maintenance of all flower biochemical and physiological processes,

\footnotetext{
'Departmento de Fisiologia Vegetal, Universidade Federal de Viçosa (UFV), 36570-900, Viçosa, MG, Brasil. E-mail: mirellebio@hotmail.com. Corresponding author.

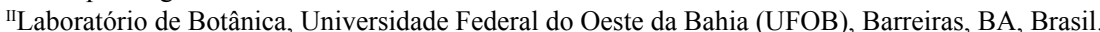


in addition to regulating the osmotic potential and working as messengers in signal transduction and gene expression (DOI \& REID, 1995).

Carbohydrates can be divided into two groups: the structural, which are cell wall components (cellulose and hemicellulose), and the non-structural, which play an important role in the distribution of dry matter between shoots and root. Sucrose and starch are the main photosynthetic products; the former is translocated in the plant to support its growth, whereas starch is the reserve carbohydrate accumulated in the chloroplasts (HEWITT et al., 1985).

In this regard, proper techniques that allow for prolonging the longevity are required. Moreover, the knowledge of the metabolism of floral carbohydrates can contribute to extending the durability of stalks during the sale period, generating greater profit and meeting the demand of consumers with species that have a longer shelf life. This study aimed to characterize the non-structural carbohydrate content in different floral stages of L. pumilum.

For the experiment, flower stalks of potted L. pumilum were supplied by a florist from Brasília$\mathrm{DF}, \mathrm{Brazil}$, at a temperature of $15^{\circ} \mathrm{C}$, relative humidity of $70 \%$, and light intensity of $7-10 \mu \mathrm{mol} \mathrm{m} \mathrm{m}^{-2} \cdot \mathrm{s}^{-1}$, after remaining $12 \mathrm{~h}$ in a cold room $\left(5^{\circ} \mathrm{C}\right)$ for acclimatization. The cut was made later in a laboratory.

A subjective scale was developed by the authors, based on which the following stages were analyzed: E0 - bud without color; E1 - but at early orange coloring; E2 - orange bud; E3 - open flower; E4 - senescent flower.

The extraction was accomplished by manually grinding the samples and filtering them with $80 \%$ ethylic alcohol. To quantify the total soluble sugars, the phenol-sulfuric acid method was employed (DUBOIS et al., 1956). Reducing sugars were determined by the Somogy-Nelson method (NELSON, 1944). Concentration of non-reducing sugars was estimated by subtracting the reducing sugars content from the total soluble sugars content. The starch hydrolysis was performed by the technique proposed by McCREADY et al. (1950).

The experiment was conducted in a randomized block design with five replicates of each developmental stage, with the experimental unit consisting of $0.3 \mathrm{~g}$ obtained from two units (bud or flower). Data were interpreted by analysis of variance, with means compared by the ScottKnott test $(\mathrm{P}>0.05)$.

The carbohydrate metabolism showed significant differences regarding the $L$. pumilum development stages (Table 1). Total soluble sugars did not differ between the initial stages (E0 and E1), with an average of $42.5 \%$, which was higher than that found in the floral opening (E2 and E3) and senescence (E4) stages, when the average total soluble sugars content was 27.0\%. Mapeli et al. (2009) observed, in Epidendrum ibaguense, an average of $24.6 \%$, referring the amount of total soluble sugars during the floral development, which was lower than the 33.3\% found in $\boldsymbol{L}$. pumilum, indicating that this species has a large energy storage.

The reducing sugars content increased significantly during the floral development, and the open or senescent flowers showed an average increase of $6.95 \%$ as compared with the buds, irrespective of the color (Table 1). This elevation can be due to the degradation of sucrose, the main sugar in translocation, which was transformed into glucose and fructose (reducing sugars) (TAIZ \& ZEIGER, 2010), which will in turn be utilized in the respiration to produce the energy used in floral opening or in the formation of metabolic intermediates.

Table 1 - Levels of TSS (total soluble sugars), RS (reducing sugars), NRS (non-reducing sugars), and starch in floral structures of Lilium pumilum at different development stages.

\begin{tabular}{|c|c|c|c|c|}
\hline \multirow{2}{*}{ Stage } & \multicolumn{4}{|c|}{--Sugar content $(\%)----$} \\
\hline & TSS & RS & NRS & Starch \\
\hline 0 & $45.6 \pm 2.3 \mathrm{~A}$ & $3.9 \pm 0.2 \mathrm{~B}$ & $41.7 \pm 2.4 \mathrm{~A}$ & $15.1 \pm 0.3 \mathrm{~A}$ \\
\hline 1 & $39.5 \pm 1.9 \mathrm{~A}$ & $3.8 \pm 0.4 \mathrm{~B}$ & $35.7 \pm 1.9 \mathrm{~A}$ & $13.2 \pm 0.4 \mathrm{~B}$ \\
\hline 2 & $27.7 \pm 1.8 \mathrm{~B}$ & $4.5 \pm 0.6 \mathrm{~B}$ & $23.2 \pm 1.7 \mathrm{~B}$ & $10.0 \pm 0.3 \mathrm{C}$ \\
\hline 3 & $30.0 \pm 0.8 \mathrm{~B}$ & $7.2 \pm 0.2 \mathrm{~A}$ & $22.9 \pm 0.7 \mathrm{~B}$ & $8.0 \pm 0.0 \mathrm{D}$ \\
\hline 4 & $23.5 \pm 1.0 \mathrm{~B}$ & $6.7 \pm 0.3 \mathrm{~A}$ & $16.7 \pm 1.2 \mathrm{~B}$ & $8.0 \pm 0.2 \mathrm{D}$ \\
\hline $\mathrm{CV}(\%)$ & 15.05 & 26.20 & 17.97 & 8.66 \\
\hline
\end{tabular}

Means followed by the same letter in the column do not differ by Scott-Knott's test at 5\% probability level. Mean \pm error. E0 - bud with no color; E1 - bud at early orange coloring stage; E2 - orange bud; E3 - open flower; E4 - senescent flower. 
The sucrose catabolism as a possible reason for the increase in the reducing sugars content can be proved by the decrease in the non-reducing sugars content, according to the development stage. The most advanced stages (E2, E3, and E4) displayed an average decrease of $21.0 \%$ in relation to stages E0 and E1.

The starch content also decreased during the floral development, with reductions of 12.6, 33.8, and $47.0 \%$, respectively, in relation to the levels of total soluble sugars comparing the bud at early coloring, orange bud, and open/senescent flower stages (Table 1). VAN DER MEULEN-MOUSERS et al. (2001) observed a reduction of 12 times in the starch content of hybrid Asian lily during floral opening, which is higher than the 1.25 times found in the present study, demonstrating that this species demands more reserve carbohydrate for the process of floral opening.

The data reveal that $\boldsymbol{L}$. pumilum has an elevated sugar content in all floral stages, which contributes to the maintenance the respiration during post-harvest.

\section{ACKNOWLEDGEMENTS}

The authors thank Coordenação de Aperfeiçoamento de Pessoal de Nível Superior (CAPES), Conselho Nacional de Desenvolvimento Científico e Tecnológico (CNPq) and Fundação de Amparo à Pesquisa do Estado da Bahia (FAPESB) for the financial support.

\section{REFERENCES}

BARBOSA, J.G. et al. Longevity of Lilies affected by stage of inflorescence development and pulsing with sucrose. Bioscience Journal, v.21, p.25-31, 2005. Available from: <http://www. seer.ufu.br/index.php/biosciencejournal/article/view/6585>. Accessed: Jan. 20, 2014

DOI, M.; REID, M.S. Sucrose improves the postharvest life of cut flowers of a hybrid Limonium. HortScience, v.30, p.1058-
1060, 1995. Available from: <http://hortsci.ashspublications.org/ content/30/5/1058.full.pdf $>$. Accessed: Feb. 13, 2014.

DUBOIS, M. et al. Colorimetric method for determination of sugars and related substances. Nature, v.28, p.350-356, 1956. Available from: $<$ http://pubs.acs.org/doi/abs/10.1021/ac60111a017>. Accessed: Feb. 13, 2014. doi: 10.1021/ac60111a017.

INSTITUTO BRASILEIRO DE FLORICULTURA (IBRAFLOR) Informativo Ibraflor. Available from: $<$ http://www.ibraflor.com.br/ ibraflor/index.php?id=23>. Accessed: Jan. 27, 2014.

HEWITT, J.D. et al. Effect of day length and night temperature on starch accumulation and degradation in soybean. Annals of Botany, v.56, p.513-522, 1985. Available from: <http://aob.oxfordjournals. org/content/56/4/513>. Accessed: Apr. 28, 2015.

MAPELI, A.M. et al. Characterisation of respiration, ethylene production and carbohydrate contents during flower opening in Epidendrum ibaguense. Journal of Horticultural Science \& Biotechnology, v.84, p.609-612, 2009. Available from: $<$ http://www. jhothortscib.org/Vol84/84 6/7.htm>. Accessed: Dec. 14, 2013.

McCREADY, R.M. et al. Determination of starch and amylase in vegetables. Analytical Chemistry, v.22, p.1156-1158, 1950. Available from: <http://pubs.acs.org/doi/abs/10.1021/ac60045a016>. Accessed: Dec. 14, 2013. doi: 10.1021/ac60045a016.

NELSON, N.A Photometric adaptation of Somogy method for the determination of glucose. Journal of Biological Chemistry, v.153, p.375-380, 1944. Available from: <http://www.jbc.org/ content/153/2/375.citation>. Accessed: Dec. 15, 2013.

SANTOS, M.H.L.C. et al. Preservative solutions in beehive ginger post-harvest. Ciência Rural, v.38, p.2354-2357, 2008. Available from: <http://www.scielo.br/scielo.php?script=sci_artt ext\&pid $=$ S010384782008000800041\&lang=pt>. Accessed: Jan. 25, 2014. doi: 10.1590/S0103-84782008000800041.

TAIZ, L.; ZEIGER, E. Fisiologia vegetal. Porto Alegre: Artmed, 2010. 819p

VAN DER MEULEN-MUISERS, J.J.M. et al. Postharvest flower development in Asiact hybrid lilies as related to tepal carbohydrate status. Postharvest Biology and Technology, v.21, p.201-211, 2001. Available from: $<$ http://www.researchgate.net/publication/222559701 Postharvest_flower_development_in_Asiatic_hybrid_lilies_as related to tepal_carbohydrate_status $>$. Accessed: Jan. 24, 2014. 